\title{
A RENOVAÇÃO DO SUPREMO TRIBUNAL FEDERAL*
}

\author{
Carlos Mário da Silva Velloso**
}

1. Palavras iniciais: o Supremo Tribunal Federal, guarda maior da Constituição. 2. A jurisdição constitucional. 3. A jurisdição constitucional no Brasil. 4. O Supremo Tribunal Federal: competências extravagantes; 4.1. Contencioso penal; 4.1.1. C.F.. art. 102, I, " $b$ ": membros do Congresso; 4.1.2. C.F., art. 102, I, "c": Ministros de Estado, Comandantes das Forças Armadas e membros do Tribunal de Contas da União; 4.1.3. C.F., art. 102. I, "d": habeas corpus; 4.1.4. C.F., art. 102, I, "i": habeas corpus; 4.1.5. C.F., art. 102, I, "g": a extradição solicitada por Estado estrangeiro; 4.2 . Contencioso de direito federal comum não penal; 4.2.1. C.F., art. 102, I, " $d$ ": mandado de segurança contra atos do T.C.U.; 4.2.2. C.F., art. 102, I, "e": litigio de Estado estrangeiro; 4.2.3. C.F., art. 102, I, "f:" litígios das entidades da administração indireta; 4.2.4. C.F., art. 102, $I$, " $h$ ": a homologação de sentença estrangeira e a concessão de 'exequatur' às cartas rogatórias; 4.3. A competência recursal ordinária: C.F., art. 102, II, "a" e "b". 5. Competência extraordinária: C.F., art. 102, III. 6. Forma de investidura do ministro do Supremo Tribunal Federal; 6.1. Ministros do Supremo Tribunal Federal: Estados de origem; 6.2. Faculdades de Direito onde se diplomaram; 6.3. Presidentes da República que nomearam ministros do Supremo Tribunal Federal; 6.4. Os ministros do S.T.F. e os Presidentes da República que os nomearam; 6.5. Análise da pesquisa; 6.6. Valeria a pena mudar o critério de escolha? 7. Proposta de alteração da forma de escolha dos ministros do S.T.F. 8. Conclusão.

* Texto básico da palestra proferida no IV Simpósio Nacional de Direito Constitucional, realizado em Curitiba, PR, promovido pela Academia Brasileira de Direito Constitucional, em 14.10.2002 ** Ministro do Supremo Tribunal Federal: Professor-Emérito das Faculdades de Direito da PUCMinas Gerais e da Universidade de Brasilia, UnB; Membro da Academia Brasileira de Letras Juridicas. 


\section{1 - Palavras iniciais: o Supremo Tribunal Federal, guarda maior da}

Constituição

Devo falar-lhes sobre o Supremo Tribunal Federal, tema desta palestra, que tenho a honra de proferir ao lado do eminente Professor Dalmo de Abreu Dallari, dos maiores juristas brasileiros.

Agradeço o convite que me fez a Academia Brasileira de Direito Constitucional, proporcionando-me este encontro com os juristas paranaenses, com os meus amigos do Paraná e de vários Estados brasileiros, aqui presentes. Agradeço, sobretudo, a oportunidade que me proporcionaram de ouvir, mais uma vez. o eminente Professor Dalmo de Abreu Dallari, a quem muito estimo, respeito e admiro.

Devo falar-lhes, especialmente, a respeito da renovação do Supremo Tribunal Federal, guarda maior da Constituição. Realmente, dispõe o art. 102, da Carta da República, que compete ao Supremo Tribunal Federal, precipuamente, a guarda da Constituição. É o Supremo Tribunal Federal, portanto, a Corte Constitucional do Brasil, incumbindo-lhe guardar, proteger e fazer cumprida a Lei Maior.

\section{2 - A jurisdição constitucional}

A jurisdição constitucional visa a tornar realidade a supremacia constitucional, supremacia constitucional que, tenho registrado en votos e conferências, constitui, segundo bons constitucionalistas, Pinto Ferreira, por exemplo, o alicerce do moderno direito político, do moderno direito público.

Se a Constituição é pressuposto de validade e da eficácia de toda a ordem normativa instituída pelo Estado, a sua supremacia deve ser tornada realidade.

O constitucionalismo apresenta três etapas: numa primeira, surge a idéia de Constituição, na segunda metade do Século XVIII, no bojo das revoluções americana, de 1776, e francesa, de 1789, idéia que, entretanto, não foi simplesmente imaginada por um homem, por um filósofo, mas que se formou através dos séculos, forte nos pactos e nos forais ou cartas de franquia, presentes, aqueles, principalmente na história constitucional inglesa, e estes últimos, em toda a Europa ocidental. As Leis Fundamentais do Reino, próprias da França, por sua vez, também são antecedentes da idéia de Constituição que eclodiu com os movimentos revolucionários aludidos, sob a inspiração dos iluministas e dos enciclopedistas. A idéia de Constituição, nos moldes como a conhecemos, é contemporânea das primeiras Declarações de Direito, a de Virgínia, de 1776, e a Declaração dos Direitos do Homem e do Cidadão, da Revolução Francesa, de 1789.

A segunda etapa do constitucionalismo resume-se no reconhecimento de que a Constituição é uma lei, uma super lei, que deve ser cumprida, a todo modo.

Finalmente, a terceira etapa é o reconhecimento de que a Constituição deve ser protegida. É dizer, deve existir um controle da constitucionalidade das normas e dos atos administrativos. 
Louis Favoreu, Biscaretti Di Ruffia e Mauro Cappelletti anotam que esse controle de constitucionalidade alcançou notável desenvolvimento no Século XX. Cappelletti registra o florescimento do controle, nos países europeus, principalmente após a $2^{\mathrm{a}}$ Guerra, com a sua consolidação e alargamento, onde já se implantara, e a sua introdução onde ainda não existia ${ }^{1}$. As causas do florescimento da jurisdição constitucional são estas: a) o renascimento do constitucionalismo após a $2^{\mathrm{a}}$ Guerra; b) a redescoberta da idéia de Constituição como breviário do povo livre; c) a necessidade de proteger e guardar a Constituição. É que os povos do velho mundo tinham se esquecido da Constituição. Sentiram, então, na própria carne os desmandos do Estado autoritário: o nazismo na Alemanha, o fascismo na Itália, o franquismo na Espanha, o salazarismo em Portugal. E o que dizer do que ocorreu nos países da Europa oriental.

Tem-se, pois, a partir do pós $2^{a}$ Guerra, o florescimento da jurisdição constitucional nos seus dois aspectos: a jurisdição constitucional propriamente dita, ou seja, controle de constitucionalidade, e jurisdição constitucional das liberdades.

A Constituição da Áustria, de 1920, sob a inspiração de Hans Kelsen, criara a Corte Constitucional austríaca, aperfeiçoada com a reforma constitucional de 1929, também sob a inspiração de Kelsen. A Corte foi suprimida, entretanto, em 1938, com a ocupação alemã. A Tchecoslováquia e a Espanha, em 1921 e 1931, respectivamente, criaram as suas Cortes Constitucionais, que tiveram vida curta ${ }^{2}$. Após a $2^{a}$ Guerra, repito, é que foi marcante o florescimento da jurisdição constitucional. Em 1945, a Corte Constitucional austríaca foi reaberta. A Constituição italiana, de 1947. com vigência a partir de $1^{\circ}$ de janeiro de 1948 , criou a Corte Constitucional da Itália. O mesmo ocorreu com a Alemanha Federal, com a Lei Fundamental de Bonn, de 1949. Seguiu-se a instituição de Cortes Constitucionais no Chipre, em 1960; na Turquia, em 1961; na Iugoslávia, de 1963 a 1974; na Tchecoslováquia, em 1968; na Grécia, em 1975; em Portugal, com a primeira reforma da Constituição de 1976, ocorrida em 1982; na Espanha, em 1978 e na Polônia, em 1986.

Essas Cortes exercem controle de constitucionalidade concentrado. Constituem elas o modelo europeu continental de jurisdição constitucional ou de justiça constitucional.

Desde 1803, nos Estados Unidos, a partir do famoso caso Marbury vs. Madison, decidido pela Suprema Corte, que se instituíra, entretanto, o controle de constitucionalidade denominado difuso, porque praticado por qualquer juiz ou tribunal, num caso concreto.

I Mauro Cappelletti, "O Controle Judicial da Constituição das Leis no Direito Comparado", Sérgio Fabris Editor, 1984. "Necesidad y Legitimidad de la Justicia Constitucionales", in "Tribunales Constitucionales Europeos y Derechos Fundamentales", L. Favoreu et alii, Centro de Estudios Constitucionales, Madrid, 1984, pg. 599 e segs.

2 Ana Cândida da Cunha Ferraz, “Apontamentos sobre o Controle de Constitucionalidade”. Rev. da Proc. Geral do Estado de São Paulo, 34/27. 


\section{3 - A jurisdição constitucional no Brasil}

Em palestra que proferi em Belo Horizonte, no "Encontro Minas-Brasília de Juízes Federais", em 29 de novembro de 2000, lembrei que a Constituição do Império, de 1824, consagrava o controle político. Com a República, adotamos o controle jurisdicional, segundo o padrão norte-americano, controle difuso, portanto. Este foi o modelo consagrado na Constituição republicana de 1891. A Constituição de 1934 "introduz a 'ação direta interventiva', modalidade de controle de constitucionalidade que se aproxima do modelo concentrado, vez que o único foro competente para julgá-la era o Supremo Tribunal Federal", cuja decisão representava um prius para a intervenção federal no Estado-membro ${ }^{3}$. E mais: estabeleceu a Constituição de 1934 que a decisão de inconstitucionalidade somente seria tomada pelo voto da maioria absoluta dos membros dos Tribunais e atribuiu ao Senado competência para suspender a execução de lei declarada inconstitucional pelo Supremo Tribunal Federal. A Carta de 1937, que simplesmente dava forma de legalidade à ditadura do Estado Novo, trouxe retrocesso. A Constituição de 1946 restaurou o controle de constitucionalidade. A Emenda Constitucional 16, de 1965, criou a ação direta genérica, ao instituir a representação de inconstitucionalidade da competência do Supremo Tribunal Federal, que seria proposta pelo Procurador-Geral da República. E prescreveu, ademais, que a lei poderia estabelecer processo de competência originária dos Tribunais de Justiça para declarar a inconstitucionalidade de lei ou ato municipal em face da Constituição do Estado. A partir daí, portanto, passamos a contar com os dois tipos de controle, o difuso e o concentrado, em abstrato, de lei ou ato normativo federal ou estadual em face da Constituição Federal, da competência exclusiva do Supremo Tribunal Federal. A Constituição de 1967, com e sem a EC 1/69, que manteve o sistema, ampliado pela Constituição de 1988, e que criou a ação direta de inconstitucionalidade por omissão, alargou a legitimação ativa para a ação direta de inconstitucionalidade e instituiu a argüição de descumprimento de preceito constitucional fundamental. A Emenda Constitucional $n^{\circ} 3$, de 1993, criou a Ação Declaratória de Constitucionalidade, ampliando e fortalecendo o controle concentrado.

Temos, portanto, os dois tipos de controle de constitucionalidade, o controle difuso e o controle concentrado, ou em abstrato. Aquele realiza-se num caso concreto, vale dizer, numa ação entre partes, que tenha como objeto uma pretensão. $\mathrm{O}$ concentrado, em termos abstratos, numa ação direta de inconstitucionalidade, cujo objeto é a própria lei que se diz inconstitucional.

Esses dois controles apresentam vantagens e desvantagens. A professora Ana Cândida Ferraz, da Faculdade de Direito da USP, dissertou a respeito ${ }^{4}$. Segundo ela, as vantagens e desvantagens dos controles difuso e concentrado podem ser assim resumidas. Controle difuso. Vantagens: a eficácia e rapidez da decisão no caso concreto; a possibilidade de o lesado por ato inconstitucional defender-se direta e

4 Ana Cândida da Cunha Ferraz, ob. e loc. cits. 
imediatamente; a natureza "jurídica" e não "política" da questão constitucional. Desvantagens: a desarmonia dos julgados, com a desvalorização das decisões de declaração de inconstitucionalidade; a diluição do poder de controle pelas centenas de juízos e tribunais; o descrédito diante de decisões díspares. Controle concentrado. Vantagens: a certeza do direito; a economia processual: uma só decisão põe fim a milhares de ações; o aprofundamento do exame das questões de inconstitucionalidade; a maior autoridade do órgão julgador. Desvantagens: o perigo da exacerbação do poder do órgão julgador único; a subtração, na prática, da interpretação constitucional aos juízes e tribunais. Acrescentaria: a declaração de inconstitucionalidade é proferida quase que imediatamente à promulgação do ato normativo, sem que a norma seja debatida e examinada por juristas e doutrinadores. No controle difuso o julgamento pela Corte Suprema dá-se após debate exaustivo nas instâncias inferiores, o que constitui, sem dúvida, uma vantagem deste.

Temos, no Brasil, os dois tipos de controle. Podemos, então, realizar o equilíbrio entre os dois, explorando as vantagens e minimizando as desvantagens de um e de outro. Realmente, no sistema misto - controle difuso e concentrado - é possível minimizar as desvantagens de um e de outro.

O sistema que adotamos é dos mais avançados, anotando o Professor José Luiz Quadros de Magalhães, da Universidade Federal de Minas Gerais, "que o Brasil tem hoje um dos sistemas de controle de constitucionalidade e de jurisdição constitucional mais sofisticados e democráticos do mundo, juntando a herança européia de controle concentrado hoje bastante questionável e a herança norte-americana de controle difuso e jurisdição constitucional difusa"s.

Daí a minha preocupação quando vozes menos informadas propugnam pela criação, no Brasil, de Corte Constitucional segundo o modelo europeu, o que representaria "retrocesso injustificável e lamentável", dado que o sistema europeu "está atrás do nosso", caminhando "para a evolução que o nosso já conquistou".

A verdade é que temos uma Corte Constitucional que pratica os dois tipos de controle, o difuso e o concentrado.

Os procedimentos ou as competências das Cortes Constitucionais européias, segundo o magistério do ministro Oscar Dias Corrêa, podem ser agrupados em quatro grandes classes: a) contencioso quase-penal; b) contencioso dos direitos fundamentais; c) contencioso das normas; d) contencioso dos litígios entre órgãos constitucionais? ${ }^{7}$.

O Supremo Tribunal Federal realiza esses quatro contenciosos. Alguns deles de forma exagerada, é o que veremos em seguida.

As Leis 9.868, de 10.11.99 e 9.882, de 03.12.99, disciplinaram a ação direta de inconstitucionalidade e a ação declaratória de constitucionalidade, a primeira, e a argüição de descumprimento de preceito fundamental, a segunda.

5 José Luiz Quadros de Magalhães, "Reforma do Judiciário", in "Jornal da Pós-Graduação em Direito da FD. UFMG", no 12, maio/2000, pág.

6 José Luiz Quadros de Magalhães, ob. e loc. cits.

7 Oscar Dias Corrêa, "O STF Corte Constitucional do Brasil", Forense, 1987, págs. 70-72. 
Dizíamos que o Supremo Tribunal Federal é a Corte Constitucional do Brasil. É verdade. Acontece que ao Supremo Tribunal foram conferidas certas atribuições que não condizem com a sua condição de Corte Constitucional, de guarda maior da Constituição. Muitas dessas atribuições, que denomino de extravagantes, distraem a Corte, tomam o tempo que a Corte deveria destinar às magnas questões constitucionais que são levadas a sua decisão.

Sustentamos, de longa data, que muitas das competências hoje conferidas ao Supremo Tribunal Federal — originárias e recursal ordinária - devem ser transferidas para outros Tribunais e Juízos. Em 1992, em palestra que proferimos em São Paulo, no "Seminário de Direito Constitucional com vistas à reforma constitucional", promovido pelo Tribunal de Contas do Município de São Paulo ${ }^{8}$, afirmamos que "ao Supremo Tribunal, Corte Constitucional, ao qual compete, precipuamente, a guarda da Constituição, não devem ser cometidas competências de direito federal comum, senão, neste campo, aquelas de todo em todo necessário, já que o contencioso de direito federal comum é do Superior Tribunal de Justiça". Sugerimos, naquela oportunidade, a exclusão de várias questões da competência do Supremo Tribunal.

Hoje, como ontem, entendemos que devem ser suprimidas as competências do Supremo Tribunal Federal que a seguir enumeramos.

\section{1 - Contencioso penal}

\subsection{1 - C.F., art. 102, $l$, " $b$ ": membros do Congresso}

Não se justifica a competência penal originária para processar e julgar os membros do Congresso Nacional (C.F., art. 102, I, "b"). Tradicionalmente, no constitucionalismo brasileiro, a competência para o processo e julgamento dos parlamentares sempre foi do Juízo de $1^{\circ}$ grau. Foi a Emenda Constitucional $n^{\circ} 1$, de 1969, promulgada pela Junta Militar, que introduziu a competência originária do Supremo Tribunal Federal para o processo e julgamento dos deputados e senadores. Se assim não se entender, a competência deveria ser passada ao Superior Tribunal de Justiça.

\subsection{2 - C.F., art. 102, I, "c": Ministros de Estado, Comandantes das Forças Armadas e membros do Tribunal de Contas da União}

O julgamento dos Ministros de Estado, nos crimes comuns e de responsabilidade, deve ser transferido para o Superior Tribunal de Justiça, que tem competência para processar e julgar, originariamente, o habeas corpus, o mandado de segurança 
e o habeas data contra ato dessas autoridades (C.F., art. 105, I, "b" e " $\mathrm{c}$ "). O mesmo pode ser dito relativamente aos Comandantes da Marinha, do Exército e da Aeronáutica. Também a competência para o julgamento dos membros do Tribunal de Contas da União e dos chefes de missão diplomática de caráter permanente deve ser do S.T.J.

\subsection{3 - C.F., art. 102, I, "d": habeas corpus}

Os habeas corpus referidos na alínea "d", do inc. I, do art. 102, devem ser reduzidos apenas àqueles em que for paciente o Presidente da República, o VicePresidente da República, Ministro do S.T.F., o Procurador-Geral da República e membro de Tribunal Superior.

\subsection{4 - C.F., art. 102, I, " $i$ ": habeas corpus}

Ao Supremo Tribunal deve competir julgar, apenas, habeas corpus, quando o coator for Tribunal Superior que haja indeferido a ordem em única instância. Trata-se de concessão aos penalistas. Porque, na realidade, a questão penal deveria acabar no Tribunal incumbido de guardar o direito federal comum, o S.T.J.

\subsection{5 - C.F., art. 102, I, " $g$ ": a extradição solicitada por Estado estrangeiro}

Não mais se justifica a competência da alínea " $g$ ": o processo e julgamento da extradição solicitada por Estado estrangeiro. Em muitos países, o julgamento do pedido de extradição é do Juízo de $1^{\circ}$ grau. A competência, no caso, deve ser da Corte à qual compete o contencioso de direito federal comum, o S.T.J.

Dir-se-á que poderia haver sobrecarga na competência do S.T.J. Isso, entretanto, poderia ser solucionado, com facilidade, já que o S.T.J., tal como acontece com as Cortes de Cassação francesa e italiana, pode ter o número de seus juízes aumentado: a Constituição prevê, apenas, um número mínimo de juízes. O S.T.J. poderá expandir-se em seções especializadas.

\section{2 - Contencioso de direito federal comum não penal}

\subsection{1 - Mandado de Segurança contra atos do TCU: art. 102, I, "d"}

A competência originária para o julgamento de mandado de segurança contra ato do Tribunal de Contas da União deve ser do Superior Tribunal de Justiça. Reporto-me, no ponto, à conferência que proferi a respeito do tema", na qual aduzi: 
"Começo por indicar uma competência originária do Supremo Tribunal Federal que deveria ser do STJ: julgar, originariamente, os mandados de segurança contra atos do Tribunal de Contas da União. Ora, os Tribunais de Contas tiveram as suas competências aumentadas pelo constituinte de 1988, o que foi muito bom. em termos de busca da moralidade administrativa. Visando, por exemplo, a moralidade administrativa, procurando evitar a fraude contra a Constituição, no que concerne à admissão de servidores públicos, estabeleceu a Constituição que ao Tribunal de Contas da União competirá apreciar, para fins de registro, a legalidade dos atos de admissão de pessoal, a qualquer título, na administração direta e indireta, incluídas as fundações instituídas pelo Poder Público (CF, art. 70, III). Dirá o Tribunal de Contas, pois, da legalidade do ingresso do servidor público. Esta foi, na verdade, uma excelente medida adotada pelo constituinte, porque a Constituição de 1967 já exigia o concurso público para ingresso no serviço público. E aconteceu o que vimos: a Constituição foi fraudada, no ponto. De modo que, agora, haverá uma fiscalização efetiva por parte do Tribunal de Contas. Isto quer dizer que o direito administrativo, no que concerne aos servidores públicos, será interpretado pelo Supremo Tribunal Federal, no caso de o servidor, que se julgar prejudicado pela decisão do $T C U$. impetrar mandado de segurança contra ato da Corte de Contas. Imaginemos que um outro servidor, na mesma situação, prefira a ação ordinária contra a União, tendo em vista o ato do Tribunal de Contas. $O$ mandado de segurança poderá ser julgado de um modo e a ação ordinária de outro, sem possibilidade de recurso ao Supremo Tribunal, se não tiver sido instaurado o contencioso constitucional. E não haverá possibilidade de ocorrer a uniformização da jurisprudência".

Transferindo-se, para o Superior Tribunal de Justiça a competência originária para o julgamento de mandados de segurança contra atos do Tribunal de Contas da União, evitar-se-ia a possibilidade de divergência entre as duas Cortes - STF e STJ — numa mesma matéria.

\subsection{2 - Litígio de Estado Estrangeiro: art. 102, I, "e"}

A competência para julgar, originariamente, o litígio entre Estado estrangeiro ou organismo internacional e a União, o Estado, o Distrito Federal ou o Território deve, igualmente, ser do Superior Tribunal de Justiça.

Reporto-me, novamente, à conferência que proferi, acima indicada. Disse eu, no ponto:

"Em muitas das competências originárias do Supremo Tribunal poderá ocorrer o mesmo. Exemplifiquemos com a competência originária da letra e do inciso I do art. 102 da Constituição: competência do Supremo Tribunal para julgar, originariamente, o litígio entre Estado estrangeiro ou organismo internacional e a União, o Estado, o Distrito Federal ou Território. Ao 
STJ competirá, por sua vez, julgar, em recurso ordinário, as causas em que forem partes Estado estrangeiro ou organismo internacional, de um lado, e, de outro, Município ou pessoa residente ou domiciliada no País (CF, art. 105, II, c), certo que estas últimas causas são julgadas, em $I^{\circ}$ grau, pelo Juiz Federal (CF, art. 109, II). As causas - que o Supremo julga, originariamente e que o STJ julga, em recurso ordinário - poderão assentar-se num mesmo tratado, ou numa mesma lei. As interpretações poderão ser diferentes, sem possibilidade de uniformização dessa interpretação".

Na verdade, a competência da alínea $e$ é determinada em razão da pessoa. $O$ mesmo deve ser dito em relação à competência do STJ, competência recursal ordinária, inscrita no art. 105, II, "c". A matéria, portanto, pode ser a mesma, o Tratado pode ser o mesmo. Divergindo as Cortes, no âmbito puramente do direito federal, a divergência poderá ser irremediável, dado que, se a questão não comportar o contencioso constitucional, não haverá recurso extraordinário. Principalmente por isso, penso que a competência da alínea $e$ deve ser do Superior Tribunal de Justiça.

\subsection{3 - Litígios das entidades da administração indireta: art. 102, $I$, " $f$ "}

A competência da alínea " $f$ ", à primeira vista, pode parecer que deva ser do STJ. No ponto, entretanto, penso que a matéria, por interessar sobremaneira à federação, deve ser da competência do Supremo Tribunal Federal. Menos, é certo, a competência para o julgamento das ações da administração indireta. Suprimiria, portanto, na alínea "f", a frase: "inclusive as respectivas entidades da administração indireta". Estas causas, de regra, ficam bem no contencioso ordinário. Quer dizer, devem ser julgadas pelo juiz de $1^{\circ}$ grau, com os recursos cabíveis.

\subsection{4 - A homologação de sentença estrangeira e a concessão de "exequatur" às cartas rogatórias: art. $102, I$, " $h$ "}

Não há motivo relevante que justifique a competência da Corte Constitucional, no caso. A homologação de sentença estrangeira dificilmente provoca discussão constitucional. As questões postas são, de regra, de direito processual. O mesmo pode ser dito em relação à concessão de exequatur às cartas rogatórias. A competência para a homologação de sentença estrangeira deve ser do Juízo de $1^{\circ}$ grau competente para a sua execução. $\mathrm{O}$ mesmo se diz relativamente ao exequatur às cartas rogatórias.

\section{3 - A competência recursal ordinária: art. $102, I I, " a$ " $e$ " $b$ "}

Linhas atrás, no tocante ao art. 102, I, "i", sugerimos que ao Supremo Tribunal deve competir julgar, apenas, habeas corpus quando o coator for Tribunal Superior que haja indeferido a ordem em única instância. Não se justificaria, portanto, a competência do Supremo Tribunal para julgar, em recurso ordinário, o habeas corpus 
decidido em única instância pelos Tribunais Superiores, se denegatória a decisão (C.F., art. 102, II, "a").

O recurso ordinário relativamente ao mandado de segurança, ao habeas data $\mathrm{e}$ ao mandado de injunção (C.F., art. 102, II, “a”), também não se justifica. O recurso adequado é, apenas, o extraordinário (C.F., art. 102, III).

\section{5 - Competência extraordinária: C.F., art. 102, III}

O inc. III do art. 102 deve ter a redação seguinte: III — julgar, mediante recurso extraordinário, as causas decididas em única ou última instância, por tribunal, quando a decisão recorrida: (...). O recurso extraordinário caberia, portanto, de decisão de tribunal, tal como ocorre com o recurso especial (CF, art. 105, III).

É que, do modo como se encontra redigido o inciso III, é cabível o recurso extraordinário das decisões dos órgãos recursais dos Juizados Especiais. Ora, estes foram concebidos para solucionar, em definitivo, as questões de sua competência, de regra questões dos necessitados. sem a possibilidade de recurso.

\section{6- Forma de investidura do ministro do S.T.F}

O Supremo Tribunal Federal, instalado em 28 de fevereiro de 1891, sucedeu o Supremo Tribunal de Justiça, do Império. A história do Supremo Tribunal Federal confunde-se com a história da República. Proclamada esta, a 15 de novembro de 1889 , o Decreto $n^{\circ} 510$, de 22.6.1890, significou o primeiro passo para a instituição do Supremo Tribunal Federal segundo o modelo da Suprema Corte norte-americana. O Decreto $n^{\circ} 848$, de 11.10.1890, transformou o Supremo Tribunal de Justiça no Supremo Tribunal Federal. Promulgada a Constituição republicana, a 24.02.1891, instalou-se o Supremo Tribunal Federal, no dia 28.02.1891, com quinze ministros, a maioria vinda do Supremo Tribunal de Justiça, maioria que, entretanto, "pouco se demoraria no novo Tribunal", informa Leda Boechat Rodrigues ${ }^{10}$.

A forma de investidura adotada seguiu o modelo da Suprema Corte norte-americana: nomeação pelo Presidente da República, após aprovação do Senado, de cidadão de notável saber e reputação. As Constituições que se seguiram mantiveram o modelo, com acréscimos: cidadão com notável saber jurídico e reputação ilibada, com mais de trinta e cinco e menos de sessenta e cinco anos de idade, exigindo-se a aprovação do nome pelo voto da maioria absoluta do Senado Federal (C.F., art. 101 e seu parágrafo único). É mais do que centenária, portanto, a forma adotada pelas Constituições republicanas.

10 Leda Boechat Rodrigues, "História do Supremo Tribunal Federal", Civilização Brasileira, Rio, $1965, \mathrm{I} / 7$. 


\section{1 - Ministros do Supremo Tribunal Federal: Estados de origem}

Da primeira constituição republicana, 1891, aos dias de hoje, foram nomeados 154 (cento e cinqüenta e quatro) ministros, certo que os dez primeiros integraram o Supremo Tribunal de Justiça. Pela ordem de antigüidade, o primeiro dos ministros do Supremo Tribunal Federal foi João Evangelista de Negreiros Sayão Lobato, Visconde de Sabará, nascido no Serro, Minas Gerais. O mais moderno é o Ministro Gilmar Mendes, natural de Mato Grosso.

Vejamos os Estados de origem dos ministros. O Estado de Alagoas deu ao Supremo Tribunal 02 ministros; o Amazonas, 01 ministro; a Bahia, 14 ministros; o Ceará, 04 ministros; o Espírito Santo, 01 ministro; Goiás, 01 ministro; o Maranhão, 05 ministros; Mato Grosso, 02 ministros; Minas Gerais, 28 ministros; Paraíba, 05 ministros; Pernambuco, 12 ministros; Piauí, 05 ministros; Paraná, 01 ministro; Rio de Janeiro, 30 ministros; Rio Grande do Norte, 01 ministro; Rio Grande do Sul, 15 ministros; Santa Catarina, 01 ministro; São Paulo, 22 ministros; Sergipe, 04 ministros.

O Rio de Janeiro, que foi sede do Supremo Tribunal, até 1960, por quase setenta anos, foi o Estado que mais ministros deu ao Supremo Tribunal: 30 ministros; segue-se o Estado de Minas Gerais, 28 ministros e o Estado de São Paulo, 22 ministros ${ }^{11}$.

\section{2 - Faculdades de Direito onde se diplomaram}

Universidade do Amazonas, 01 ministro; Universidade Federal da Bahia, 03 ministros; Universidade Federal do Ceará, 02 ministros; Universidade de Brasília, UnB, 01 ministro; Universidade Federal do Maranhão, 01 ministro; Universidade Federal de Minas Gerais, 12 ministros; Faculdades de Direito de Olinda e Recife (UFPE), 40 ministros; Faculdades de Direito do Rio de Janeiro, 31 ministros; Universidade Federal do Rio Grande do Sul, 07 ministros; Pontifícia Universidade Católica do Rio Grande do Sul, 01 ministro: Universidade de São Paulo, USP, 53 ministros; Law School Union University, Albany, New York, 01 ministro (ministro Amaro Cavalcanti) ${ }^{12}$.

11 Fonte: Supremo Tribunal Federal: site: .

12 Fonte: Supremo Tribunal Federal: idem. 


\begin{tabular}{|l|c|}
\hline Manoel Deodoro da Fonseca & 15 Ministros \\
\hline Floriano Vieira Peixoto & 15 Ministros \\
\hline Prudente José de Moraes Barros & 07 Ministros \\
\hline Manoel Victorino Pereira $\left(^{*}\right)$ & 03 Ministros \\
\hline Manoel Ferraz de Campos Salles & 02 Ministros \\
\hline Francisco de Paula Rodrigues Alves & 05 Ministros \\
\hline Affonso Augusto Moreira Penna & 02 Ministros \\
\hline Nilo Peçanha & 02 Ministros \\
\hline Hermes Rodrigues da Fonseca & 06 Ministros \\
\hline Wenceslau Braz Pereira Gomes & 04 Ministros \\
\hline Delfim Moreira da Costa Ribeiro & 01 Ministro \\
\hline Epitácio da Silva Pessoa & 03 Ministros \\
\hline Arthur da Silva Bernardes & 05 Ministros \\
\hline Washington Luís Pereira de Sousa & 04 Ministros \\
\hline Getúlio Dorneles Vargas & 21 Ministros \\
\hline José Linhares $(*)$ & 03 Ministros \\
\hline Eurico Gaspar Dutra & 03 Ministros \\
\hline Nereu de Oliveira Ramos $(*)$ & 01 Ministro \\
\hline Juscelino Kubitschek de Oliveira & 04 Ministros \\
\hline Jânio da Silva Quadros & 01 Ministro \\
\hline João Belchior Marques Goulart & 02 Ministros \\
\hline Humberto Alencar Castelo Branco & 08 Ministros \\
\hline Artur da Costa e Silva & 04 Ministros \\
\hline Emílio Garrastazu Médici & 04 Ministros \\
\hline Ernesto Geisel & 07 Ministros \\
\hline João Baptista de Oliveira Figueiredo $(* *)$ & 09 Ministros \\
\hline José Sarney & 05 Ministros \\
\hline Fernando Affonso Collor de Mello $\left(^{* *}\right)$ & 04 Ministros \\
\hline Itamar Augusto Cautiero Franco & 01 Ministro \\
\hline Fernando Henrique Cardoso & 03 Ministros \\
\hline
\end{tabular}

(*) Exerceu a Presidência da República, na condição de substituto eventual do Chefe do Poder Executivo.

(**) Os Presidentes João Baptista de Oliveira Figueiredo e Fernando Affonso Collor de Mello nomearam o ministro Francisco Rezck em 1983 e em 1992, respectivamente.

NOTA: JOĀO CAFÉ FILHO (1954-1955) foi o único Presidente da República que, durante o seu mandato, não indicou nem nomeou Ministro para o STF. 
O Presidente da República que mais ministros nomeou foi Getúlio Vargas (21 ministros). Vieram, depois, os Presidentes Deodoro da Fonseca e Floriano Peixoto (15 ministros/cada). Os Presidentes João Figueiredo e Castelo Branco nomearam 9 e 8 ministros, respectivamente.

\section{4 - Os ministros do S.T.F. e os Presidentes da República que os nomearam}

Vejamos os nomes dos ministros e os Presidentes que os nomearam. Vamos relacionar os nomeados a partir de $1940^{13}$ :

1) Castro Nunes - Getúlio Vargas;

2) Orozimbo Nonato - Getúlio Vargas;

3) Waldemar Falcão - Getúlio Vargas;

4) Goulart de Almeida - Getúlio Vargas;

5) Philadelpho Azevedo - Getúlio Vargas;

6) Lafayette de Andrada - José Linhares;

7) Edgard Costa - José Linhares;

8) Ribeiro da Costa - José Linhares:

9) Hahnemann Guimarães - Eurico Dutra;

10) Luis Gallotti - Eurico Dutra:

11) Rocha Lagoa - Eurico Dutra;

12) Mário Guimarães - Getúlio Vargas;

13) Nelson Hungria - Getúlio Vargas;

14) Ari Franco - Nereu Ramos:

15) Cândido Mota - Juscelino Kubitschek;

16) Vilas Boas - Juscelino Kubitschek;

17) Gonçalves de Oliveira - Juscelino Kubitschek;

18) Victor Nunes - Juscelino Kubitschek;

19) Pedro Chaves - Jânio Quadros;

20) Hermes Lima - João Goulart;

21) Evandro Lins - João Goulart:

22) Adalício Nogueira - Castelo Branco:

23) Prado Kely - Castelo Branco;

24) Oswaldo Trigueiro - Castelo Branco;

25) Aliomar Baleeiro - Castelo Branco;

26) Carlos Medeiros - Castelo Branco;

27) Eloy da Rocha - Castelo Branco;

28) Djacy Falcão - Castelo Branco;

29) Adauto Cardoso - Castelo Branco;

30) Barros Monteiro - Costa e Silva;

31) Temístocles Cavalcante - Costa e Silva:

32) Amaral Santos - Costa e Silva:

33) Thompson Flores - Costa e Silva;

13 Fonte: Supremo Tribunal Federal: site: . 
34) Bilac Pinto - E. Médici;

35) Antônio Neder - E. Médici:

36) Xavier de Albuquerque - E. Médici;

37) Rodrigues Alckmin - E. Médici;

38) Leitão de Abreu - Ernesto Geisel;

39) Cordeiro Guerra - Ernesto Geisel;

40) Moreira Alves - Ernesto Geisel;

41) Cunha Peixoto - Ernesto Geisel:

42) Soares Muñoz - Ernesto Geisel;

43) Décio Miranda - Ernesto Geisel:

44) Rafael Mayer - Ernesto Geisel:

45) Clóvis Ramalhete - João Figueiredo;

46) Firmino Paz - João Figueiredo;

47) Néri da Silveira - João Figueiredo;

48) Alfredo Buzaid - João Figueiredo;

49) Oscar Corrêa - João Figueiredo;

50) Aldir Passarinho - João Figueiredo;

51) Francisco Rezek - João Figueiredo;

52) Sydney Sanches - João Figueiredo;

53) Octavio Gallotti - João Figueiredo;

54) Carlos Madeira - José Sarney;

55) Célio Borja - José Sarney;

56) Paulo Brossard - José Sarney;

57) Sepúlveda Pertence - José Sarney;

58) Celso de Mello - José Sarney;

59) Carlos Velloso - Fernando Collor;

60) Marco Aurélio - Fernando Collor;

61) Ilmar Galvão - Fernando Collor;

62) Francisco Rezek - Fernando Collor:

63) Maurício Corrêa - Itamar Franco;

64) Nelson Jobim - Fernando Henrique;

65) Ellen Gracie - Fernando Henrique;

66) Gilmar Mendes - Fernando Henrique.

\section{5 - Análise da pesquisa}

Da pesquisa acima, verifica-se: a) as Faculdades de Direito de maior prestígio, São Paulo, Pernambuco, Minas, Rio de Janeiro e Rio Grande do Sul foram as que mais ministros deram ao Supremo Tribunal Federal; b) os Estados de maior tradição jurídica forneceram ao Supremo Tribunal maior número de ministros: Rio de Janeiro, Minas, São Paulo, Pernambuco, Bahia e Rio Grande do Sul; c) os juristas nomeados para o Supremo Tribunal Federal, constantes da relação acima transcrita, são cidadãos de saber jurídico, uns mais, outros menos, nenhum, entretanto, desmerecedor 
da nomeação; d) os Presidentes da República, de modo geral, escolheram bem; e) nada se pode dizer contra a reputação moral dos nomeados; f) a restrição, a um ou outro nome, constituiria exceção.

\section{6 - Valeria a pena mudar o critério de escolha?}

Posta a questão nestes termos, indaga-se: valeria a pena mudar o critério de escolha dos juízes do Supremo Tribunal Federal?

Esta é a primeira questão que ponho à reflexão dos participantes deste Simpósio. Num evento científico, não se admitem preconceitos. A reflexão, pois, há de ser feita em termos científicos.

\section{7 - Proposta de alteração da forma de escolha dos ministros do Supremo Tribunal Federal}

Todavia, se se entende que seria conveniente a mudança do critério de escolha dos juízes do Supremo Tribunal Federal, submeto à consideração dos participantes deste Simpósio as seguintes sugestões.

Em primeiro lugar, indaga-se: deveria ser mantida a vitaliciedade dos membros da Corte? Penso que sim, tendo em consideração que o Supremo Tribunal Federal realiza o controle difuso, mediante o recurso extraordinário. O exemplo da Suprema Corte americana, cujos juízes são vitalícios e permanecem no cargo enquanto bem servirem, não deve ser deixado de lado. No Brasil, tem-se uma vitaliciedade mitigada, dado que o ministro se aposenta, compulsoriamente, aos setenta anos de idade.

Não tenho preconceito, entretanto, relativamente ao mandato. No Tribunal Constitucional português, os juizes têm mandato de seis anos, podendo ser reeleitos uma vez. No Tribunal Constitucional alemão, o mandato dos juízes é de doze anos. No Tribunal Constitucional italiano, que se compõe de quinze juízes, o mandato é de nove anos. No Tribunal Constitucional espanhol, tal como na Itália, é de nove anos. É de se observar que essas Cortes Constitucionais realizam, apenas, controle concentrado. Se se optasse pelo mandato, sugerimos doze anos, tal como ocorre no Tribunal Constitucional alemão.

No que toca, especificamente, à forma de escolha dos juízes do Supremo Tribunal Federal, reitero sugestão que apresentei na palestra que proferi, em novembro de 2001, no Seminário "O Supremo Tribunal Federal na História Republicana", promovido pela Associação dos Juízes Federais e realizado no Centro Cultural da Justiça Federal (antiga sede do STF), no Rio de Janeiro ${ }^{14}$.

A proposta pode ser assim resumida: as Universidades, pelas suas Faculdades de Direito, indicariam dois nomes entre professores de Direito; os Tribunais Supe-

14 Carlos Mário da S. Velloso, “O Supremo Tribunal Federal como Tribunal Constitucional”, in Anais do Seminário "O STF na História Republicana”, AJUFE, Rio de Janeiro, Dupligráfica Editora Ltda., 2002, págs. 283 e segs. 
riores indicariam, também, dois nomes de juízes do respectivo Tribunal; o mesmo ocorreria com o Conselho Federal da OAB, com o Conselho Superior do Ministério Público Federal, com os Conselhos Superiores dos Ministérios Públicos estaduais e com as associações de magistrados de âmbito nacional. Os indicados deveriam satisfazer os requisitos exigidos no art. 101 da Constituição e deveriam contar com mais de vinte anos de exercício no magistério superior, na magistratura, no Ministério Público ou na advocacia. Os nomes seriam indicados ao Supremo Tribunal Federal que, em sessão pública, elegeria, dentre eles, seis nomes. A lista sêxtupla seria encaminhada ao Presidente da República, que escolheria um nome, que seria levado à aprovação, ou não, da maioria absoluta do Senado Federal. O candidato seria submetido, no Senado, à sabatina, da qual participariam representantes dos órgãos indicadores dos candidatos - Universidades. Tribunais Superiores, Conselho Federal da OAB, Conselhos Superiores do Ministério Público e associações de magistrados de âmbito nacional.

A nomeação, nesses termos, adquiriria transparência e teria maior legitimidade.

\section{$8-$ Conclusão}

Senhoras e Senhores, ao convocar-lhes a refletirem sobre o tema, reitero o que tenho afirmado em palestras e mesmo em votos: as instituições políticas são muito importantes na vida de uma Nação. Fazer com que elas sejam cada vez mais respeitadas, é nosso dever. A história do Supremo Tribunal Federal, retorno às minhas primeiras palavras, se confunde com a história da República. "Elas se interligam e se integram nas grandezas e vicissitudes, nos dias de glória e nos instantes de sombra", anotou o Senador José Sarney ${ }^{15}$. A grandeza da República, não tenho dúvida, está na razão direta da grandeza da Corte que se incumbe de torná-la realidade, na medida em que faz cumprida e respeitada a Constituição. A reflexão, portanto, em torno do tema - a renovação do Supremo Tribunal - há de ser feita em termos puramente científicos, porque, a despeito das vicissitudes da República e, em consequiência, das vicissitudes do Supremo Tribunal, penso que continua atual a sentença de Levi Carneiro, de que o Supremo Tribunal Federal é a "jóia das instituiçôes republicanas brasileiras".

Que assim seja, hoje e sempre.

15 Senador José Sarney, discurso proferido na Sessão Especial realizada pelo Senado Federal em comemoração ao Centenário de instalação do S.T.F. Senado Federal, Brasília, DF, 19.04.91. 